\title{
ScIjentijific Note \\ Nest camouflage records on five social wasp species (Vespidae, Polistinae) from southeastern Brazil
}

\author{
Marcos Magalhães de Souza1 ${ }^{1 \otimes}$, Mateus Aparecido Clemente ${ }^{2 ®}$ \& Gabriel Teofilo-Guedes ${ }^{3 \oplus}$
}

\begin{abstract}
1. Instituto Federal de Educação, Ciência Tecnologia do Sul de Minas, Campus Inconfidentes, Brazil. 2. Universidade Estadual Paulista Júlio de Mesquita Filho, Instituto de Biociências, Zoology Department, Brazil. 3. Universidade Estadual de Campinas, Instituto de Geociências, Brazil.
\end{abstract}

\section{EntomoBrasilis 13: e929 (2020)}

\section{Edited by:}

Rafael Boldrini

Article History:

Received: 27.viii.2020

Accepted: 04.xi.2020

Published: 16.xi.2020

Corresponding author:

Marcos Magalhães de Souza

७ marcos.souza@ifsuldeminas.edu.br

Funding agencies:

$\Delta$ Without funding declared

\begin{abstract}
Social insects adopt different strategies to defend their colonies, including camouflage. Aiming to increase the knowledge about this strategy on social wasps, in this study we present records of nest camouflage for Parachartergus smithii (de Saussure), Parachartergus wagneri du Buysson, Chartergellus communis Richards, Metapolybia cingulata (Fabricius) and Mischocyttarus anthracinus Richards, being is last, P. smithii and P. wagneri are poorly discussed within the specialized literature regarding their nesting behavior. Therefore, we made records in different conservation units, between 2011 and 2019, in Minas Gerais state, southeastern Brazil. We point out that, due to their docile behavior, the camouflage appears to be the main defense strategy for these species, as demonstrated by the color and shape of the nests within the substrate. The exception is M. cingulata, which presents both camouflage and aggressive behavior in some situations.
\end{abstract}

Keywords: Chartergellus; Colony Defense; Metapolybia; Parachartergus.
Docial insects present different evolutionary adaptations to protect their colonies, such as chemical defense (Jeanne 1970), aggressive behavior (BRito et al. 2018), associations with other animals (Menezes et al. 2014; Le GUEN et al. 2015; SouzA et al. 2017) and strategies related to the nest architecture (ChavarríA-PIzARRo \& West-Eberhard 2010). Colony architecture studies allow obtain Information about nest building and repair, social organization and ecological relations, as seen for Charterginus, Pseudopolybia, Polistes, Mischocyttarus and other genera (e.g. JEANNE 1975; RICHARDS 1978; Odonnel \& Jeanne 1990; London \& JeAnNe 1998, 2000, 2003; Montagna et al. 2010; Felizardo et al. 2018).

Since maintaining the colony is vital for the survival of social wasps, an important ecological strategy for colony defense is nest camouflage (RIChards 1978; Wenzel 1998; Mateus et al. 1997), which in some species presents a high elaboration degree, so that the colonies become undetectable against the substrate (HERMANN \& BLUM 1981).

Considering behavioral aspects for more aggressive species, the stinger appears to be sufficient; however, docile species usually adopt other strategies, such as Parachartergus colobopterus (Lichtenstein), which uses camouflage to defend its colonies (Strassmann et al. 1990). This is also true for Mischocyttarus species (RICHARDS 1978; GIANnOtTI 1999; SILVEIRA et al. 2015), and other genera such as Nectarinella (WENZEL 1998) and Leipomeles according to (STARR, 1991).

In order to contribute to the current knowledge on social wasps nesting and colony defense behavior, we present nest camouflage records for Parachartergus smithii (de Saussure), Parachartergus wagneri du Buysson, Chartergellus communis Richards, Metapolybia cingulata (Fabricius) and Mischocyttarus

\section{anthracinus Richards.}

We recorded the nests in five conservation units in Minas Gerais state, southeastern Brazil: in the Atlantic forest areas such as Environmental Protection Area of Machado River

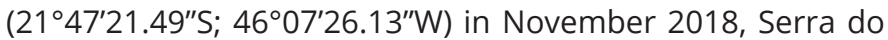

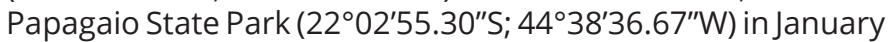
2017, and Rio Doce State Park (19³9'59.66"S; 42³2'57.09"W) January 2011 and in the Cerrado areas such as Pandeiros

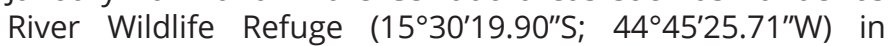
October 2014, and Sempre Vivas National Park (43\%46'3712"S; 17048'22.17"W) between October 2018 and March 2019.

Active searches for colonies were carried out between 9 am and $4 \mathrm{pm}$. Once the colony was found, a photographic record was made, alongside notes regarding the different characteristics of the number of colonies, substrate, ground height (m), camouflage, behavior and locality (Table 01). Additionally, we caused disturbances to the colony, by touching it and registering the behavior of the individuals for the next 25 to 30 minutes using the ad libitum method (DeLCLARO 2010), considering it docile behavior when individuals remain inside the nest and / or dispersed in flight, and aggressive, when they fly around the source of disturbance and try to sting (STRASSMANn et al. 1990). Then, we collected around three to five individuals for species identification and prepared them for dry preservation. Finally, we integrated the specimens into the IFSULDEMINAS Campus Inconfidentes and Emílio Goeldi Paraense Museum social wasps biological collections within the SpeciesLink Network (2020). The specimens where identified by Dr. Orlando Tobias da Silveira, from Emílio Goeldi Museum.

Concerning P. smithii (Figure $1 \mathrm{~A}$ and $1 \mathrm{~B}$ ), at the time of 
registration, there were no individuals on the outside of the colony. However, the disturbance of the observed structure confirmed that it was a colony, as it prompted the exit of the individuals, which demonstrated docile behavior, remaining over the nest wrapper. The shape and gray color of the nest allows it to disappear into the substrate, which demonstrates homochromy or homotype camouflage (Table 1). MAteus et al. (1997), for instance, reported a case of a $P$. smithii nest with a light gray colored envelope, striated with brown and dark gray, which produced a camouflage for the nest.

Parachartergus wagneri (Figure 1C and 1D) did not present individuals on the colony surface, at the time of registration. However, disturbances in the nest prompted the exit of individuals through the opening in the posterior portion of the nest, also cryptic due to its adherence to the tree trunk. Outside the nest, the individuals remained immobile, not attacking, then flying around due to the disturbance persistence. Such docile behavior seen in $P$. wagneri suggests the adoption of alternative strategies of colony defense. Also, the gray color similarity between the nest and the vegetal substrate reinforces the hypothesis of camouflage (Table 1).

Metapolybia cingulata nests presented a gray color similar to the trunk or the wood used in nesting, which suggests homochromic camouflage. However, when the nest is similar to the shape of the trunk bark, a camouflage of the homotype kind is suggested (Figure 1E), as reported by SomaviLLA et al. (2012). Therefore, camouflage in this species is based on two simultaneous strategies, homotype and homochromia. In addition, the nests of this genus are of the astelocyttarus type (RICHARDS \& RICHARDS 1951), where the single honeycomb is firmly adhered to the substrate, making its distinction difficult. Differently from the species of Parachartergus and Chartergellus, the individuals of $M$. cingulata presented aggressiveness when the intentional disturbances, by dispersing and investing in attempts to sting. This suggests camouflage and aggressiveness as joint defense mechanisms (Table 1) (Chavarría-Pizarro \& West-Eberhard 2010).

In the case of $C$. communis (Figure 1F) the shape of the nests combined with their coloring made them difficult to distinguish in the environment (Table 1). Their behavior was similar to that shown by P. smithii (MATEus et al. 1997), $P$. colobopterus (StRASSMANn et al. 1990), Chartergellus punctatior Richards, and Chartergellus golfitensis West-Eberhard (Chavarría-Pizarro \& West-Eberhard 2010).

Similar reports were made for Metapolybia and for Synoeca species, which, although building camouflaged nests, show aggressive behavior when there are disturbances external to the colony (Chavarría-PizarRo \& West-Eberhard 2010). In this sense, it must be mentioned that the alternation between aggressiveness and docile behavior is directly associated with the stage of the colony, being docile in nests with low productivity and aggressive when increasing the production of eggs and pupae, as described for Metapolybia aztecoides Richards (FORSYTH 1978).

Regarding color and shape of $M$. anthracinus colonies, there is considerable similarity with the capitulum type inflorescence of the Asteraceae (Figure 1G). This makes the identification of the nest hard within the environment. Therefore, we infer, once again, nest camouflage based on shape and color. When there was an approach to the colony, the individuals flew away or remained in it, moving to the opposite side of the nest, without any aggressiveness. Due to the susceptibility of some species of the Mischocyttarus genus to predators in colonies with few individuals and lacking a protective wrapper due to factors such as stunted stingers (JEANNE 1975; RAPOSO-FILHo \& Rodrigues 1984), direct and indirect defense strategies can be observed. In this regard, camouflage is a relevant strategy for the genus, as demonstrated by recent studies (e.g. Barbosa et al. 2016, Milani et al. 2020).

We conclude that camouflage is the main defense strategy in colonies of $P$. smithii, $P$. wagneri, $C$. communis and $M$. anthracinus, while for $M$. cingulata it is adopted in combination with aggressive behavior.

\section{REFERENCES}

Barbosa, BC, ML Dias, KM Vieira \& F Prezoto, 2016. Cryptic Nest of Mischocyttarus iheringi (Hymenoptera: Vespidae: Polistinae) with Description of Camouflage. Florida Entomologist, 99: 135-138. DOI: https://doi.org/10.1653/024.099.0130

Brito, ELS, M Aragão \& GMM Santos, 2018. Colony defensive behavior by the swarm-founding wasp Parachartergus pseudoapicalis: increase on investment predicts the intensity of nest defense. Insectes Sociaux, 65: 411-417. DOI: https://doi.org/10.1007/s00040-018-0627-6

Chavarria-Pizarro, L \& MJ West-Eberhard, 2010. The behavior and natural history of Chartergellus a little-known genus of neotropical social wasps (Vespidae: Polistinae: Epiponini). Ethology Ecology \& Evolution, 2: 317-343. DOI: https://doi.org/10.1080/03949370.2010.510035

Del-Claro, K, 2010. Introdução a Ecologia Comportamental, um manual para o estudo do comportamento animal. Rio de Janeiro: Technical Books press.

Felizardo, SPS, IPV dos Santos \& OT Silveira, 2018. Notes on the nest of the social wasp Pseudopolybia langi (Hymenoptera. Vespidae, Polistinae). Revista Brasileira de Entomologia, 62: 90-96. DOI: https://doi.org/10.1016/j.

Table 1. Number of colonies, substrate used for nesting, height of the nest in relation to the ground, camouflage strategy used (regarding color and shape), behavior (docile or aggressive) and place of registration (RVS = Pandeiros River Wildlife Refuge; PN = Sempre Vivas National Park; PE = Rio Doce State Park and Serra do Papagaio State Park; APA = Environmental Protection Area of Machado River) of different species of social wasps in the state of Minas Gerais, southeastern Brazil.

\begin{tabular}{|c|c|c|c|c|c|}
\hline Species & $\begin{array}{c}\text { Parachartergus } \\
\text { smithii (de Saussure) }\end{array}$ & $\begin{array}{c}\text { Parachartergus } \\
\text { wagneri du Buysson }\end{array}$ & $\begin{array}{l}\text { Chartergellus } \\
\text { communis Richards }\end{array}$ & $\begin{array}{l}\text { Metapolybia cingulata } \\
\text { (Fabricius) }\end{array}$ & $\begin{array}{l}\text { Mischocyttarus } \\
\text { anthracinus Richards }\end{array}$ \\
\hline $\mathbf{N}^{\circ}$ of colonies & 2 & 1 & 4 & 12 & 1 \\
\hline Substrate & Trunk & Trunk & Trunk and light post & $\begin{array}{c}\text { Trunk and roofing } \\
\text { woods }\end{array}$ & Inflorescence \\
\hline Ground height (m) & Raging from 8 to 10 & 4 & Raging from 0,5 to 8 & Raging from 1 to 9 & 1 \\
\hline Camouflage & Color and shape & Color and shape & Color and shape & Color and shape & Color and shape \\
\hline Behavior & Docile & Docile & Docile & Docile /aggressive & Docile \\
\hline \multirow[t]{2}{*}{ Locality } & RVS Rio Pandeiros & APA Rio Machado & RVS Rio Pandeiros & RVS Rio Pandeiros & $\begin{array}{l}\text { PE da Serra do } \\
\text { Papagaio }\end{array}$ \\
\hline & & & PN das sempre vivas & PE do Rio Doce & \\
\hline
\end{tabular}



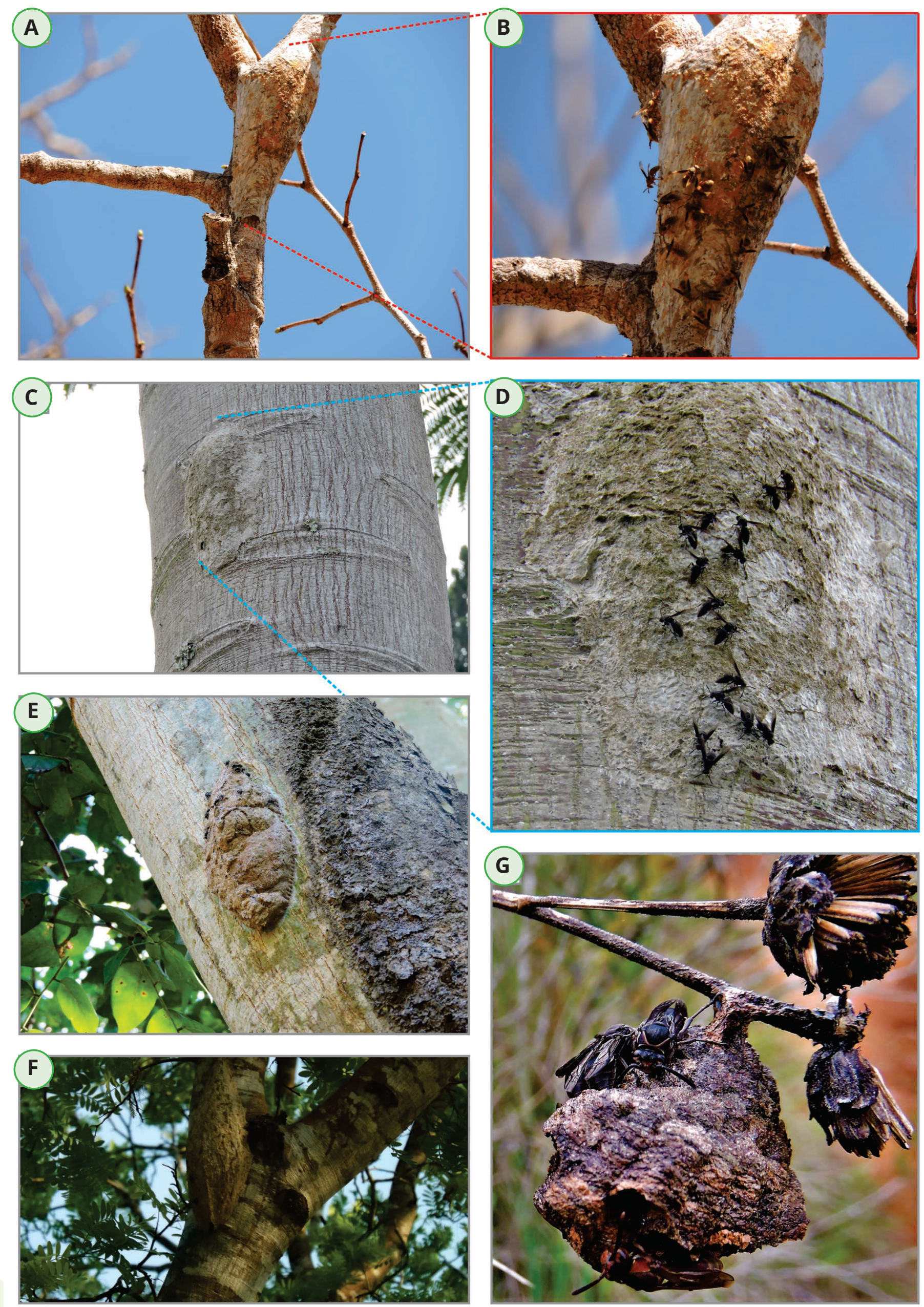

Figure 1. Camouflaged nests of social wasp species, Minas Gerais state, southeastern Brazil. A and B - Parachartergus smithii recorded at Pandeiros River Wildlife Refuge (RVS); C and D - Parachartergus wagneri recorded in the Environmental Protection Area of the Machado River; E - Metapolybia cingulata also from RVS; F - Chartergellus communis in RVS; G - Mischocyttarus anthracinus in Serra do Papagaio State Park. 
rbe.2018.02.002

Forsyth, $A B, 1978$. Studies on the behavioral ecology of polygynous social wasps, (PhD thesis). Harvard University, Cambridge, EUA.

Giannotti, E, 1999. Arquitetura de ninhos de Mischocyttarus cerberus styx Richards, 1940 (Hymenoptera, Vespidae). Revista Brasileira de Zoociências, 1: 7-18.

Hermann, HR \& MS Blum, 1981. Defensive mechanisms in the social Hymenoptera, pp. 77-97. In: Hermann, HR. (Ed.). Social insects. New York: Academic Press.

Jeanne, RL, 1970. Chemical defense of brood by a social wasp. Science, 168: 1465-1466.DOI: https://doi.org/10.1126/ science.168.3938.1465

Jeanne, RL, 1975. The adaptiveness of social wasp nest architecture. The Quarterly Review of Biology, 50: 267287. DOI: https://doi.org/10.1086/408564

Le Guen, R, B Corbara, V Rossi, F Azémar \& A Dejean, 2015. Reciprocal protection from natural enemies in an antwasp association. Comptes Rendus Biologies, 338: 255259. DOI: https://doi.org/10.1016/j.crvi.2015.02.002

London K \& RL Jeanne, 1998. Envelopes protect social wasps' nests from phorid infestation (Hymenoptera: Vespidae, Diptera: Phoridae). Journal of the Kansas Entomological Society, 71: 175-182.

London K \& RL Jeanne, 2000. The interaction between mode of colony founding, nest architecture and ant defense in polistine wasps. Ethology, Ecology and Evolution, 12: 1325. DOI: https://doi.org/10.1080/03949370.2000.9728440

London K \& RL Jeanne, 2003. Effects of colony size and stage of development on defense response by the swarm-founding wasp Polybia occidentalis. Behavioral Ecology and Sociobiology, 54(6): 539-546. DOI: https://doi.org/10.1007/s00265-003-0662-8

Mateus, S; FB Noll \& R Zucchi, 1997. Morphological caste differences in neotropical swarm-founding polistine wasps: Parachartergus smithii (Hymenoptera: Vespidae). Journal of the New York Entomological Society, 105: 129139.

Menezes, JCT, BC Barbosa, \& F Prezoto, 2014. Previously unreported nesting associations of the yellow-olive flycatcher (Tolmomyias sulphurescens) (Aves: Tyrannidae) with social wasps and bees. Ornitologia Neotropical, 55: 363-368.

Milani, LR, F Prezoto, MA Clemente, PP Gomes \& MM Souza, 2020. Nesting Behaviour of a Neotropical Social Wasp Mischocyttarus saussurei Zikán, 1949 (Hymenoptera, Vespidae). Sociobiology, 67: 121-125. DOI: https://doi.org/10.13102/sociobiology.v67i1.4842

Montagna TS, VO Torres, W Fernandes \& WF Antonialli-Junior, 2010. Nest Architecture, Colony Productivity, and Duration of Immature Stages in a Social Wasp, Mischocyttarus consimilis. Journal of Insect Science, 10:191. DOI: https://doi.org/10.1673/031.010.19101

Odonnel S \& RL Jeanne, 1990. Forager specialization and the control of nest repair in Polybia occidentalis Olivier (Hymenoptera: Vespidae). Behavioral Ecology and Sociobiology, 27: 359-364. DOI: https://doi.org/10.1007/ BF00164007

Raposo-Filho, JR \& VM Rodrigues, 1984. Habitat e local de nidificação de Mischocyttarus (Monocyttarus) extinctus Zikán, 1935 (Polistinae, Vespidae). Anais da Sociedade Entomológica do Brasil, 13: 19-28.

Richards, OW, 1978. The social wasps of the Americas, excluding the Vespinae. London: British Museum (Natural History).

Richards, OW \& MJ Richards, 1951. Observations on the social wasps of South America (Hymenoptera, Vespidae). Transactions of the Entomological Society of London, 102: 1-170. DOI: https://doi.org/10.1111/j.1365-2311.1951. tb01241.x

Silveira, OT, SS Silva \& SPS Felizardo, 2015. Notes on social wasps of the group of Mischocyttarus (Omega) punctatus (Ducke), with description of six new species (Hymenoptera, Vespidae, Polistinae). Revista Brasileira de Entomologia, 59: 154-168. DOI: https://doi.org/10.1016/j. rbe.2015.07.006

Somavilla, A; ML Oliveira \& OT Silveira, 2012. Guia de identificação dos ninhos de vespas sociais (Hymenoptera, Vespidae, Polistinae) na Reserva Ducke, Manaus, Amazonas, Brasil. Revista Brasileira de Entomologia, 56: 405-414. DOI: https://doi.org/10.1590/s008556262012000400003

Souza, MM, AG Brunismann \& MA Clemente, 2017. Species composition, relative abundance and distribution of social wasps fauna on different ecosystems. Sociobiology, 64: 456-465. DOI: https://doi.org/10.13102/sociobiology. v64i4.1839

SpeciesLink Network, 2020. Available on: <http://splink.cria. org.br> [Access in: 14.x.2020].

Starr, CK, 1991. The nest as the locus of social life. In the Social Biology of Wasps, pp. 520-539. In: Ross KG \& Matthews RW (Eds.) Ithaca: Cornell University Press.

Strassmann JE, CR Hughes \& DC Queller, 1990. Colony defense in the social wasps, Parachartergus colobopterus. Biotropica, 22: 324-327. DOI: https://doi.org/10.2307/2388546

Wenzel, JWA, 1998. Generic key to the nests of Hornets, Yellow-jackets, and paper wasps worldwide (Vespidae: Vespinae, Polistinae). American Museum Novitates, 3224: $1-39$.

$\star \star \star * \star * * * * *$

\section{Suggestion citation:}

Souza, MM, MA Clemente \& G Teofilo-Guedes, 2020. Nest camouflage records on five social wasp species (Vespidae, Polistinae) from southeastern Brazil. EntomoBrasilis, 13: e929.

Available in: doi: 10.12741/ebrasilis.v13.e929

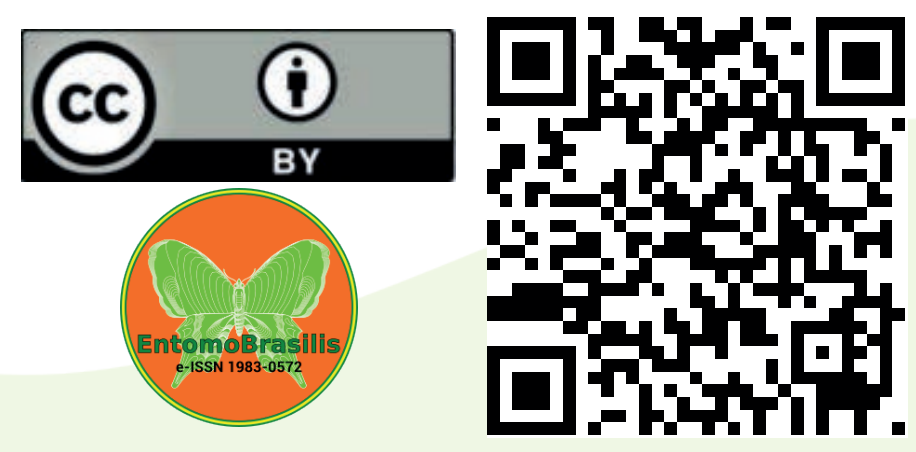

